\title{
Comparison of genome segments 2,7 and 10 of bluetongue viruses serotype 2 for differentiation between field isolates and the vaccine strain
}

\author{
Emmanuel BRÉARD ${ }^{\mathrm{a} *}$, Corinne SAILLEAU ${ }^{\mathrm{a}}$, Hervé COUPIER ${ }^{\mathrm{b}}$, \\ Karine MURE-RAVAUD ${ }^{\mathrm{b}}$, Saliha HAMMOUMI ${ }^{\mathrm{a}}$, Bernard GICQUEL ${ }^{\mathrm{a}}$, \\ Chris HAMBLIN ${ }^{\mathrm{c}}$, Philippe DUBOURGET ${ }^{\mathrm{b}}$, Stéphan ZIENTARA ${ }^{\mathrm{a}}$ \\ a UMR 1161 AFSSA-INRA-ENVA, Agence Française de Sécurité Sanitaire des Aliments - Alfort, \\ 22 rue Pierre Curie, 94703 Maisons-Alfort, France \\ b MERIAL Grande Prophylaxis Enterprise, 29 avenue Tony Garnier, 69007 Lyon, France \\ c Institute for Animal Health, Pirbright Laboratory, Ash Road, Pirbright, Surrey, GU24 ONF, UK
}

(Received 13 February 2003; accepted 23 May 2003)

\begin{abstract}
Bluetongue (BT) virus serotype 2 (BTV 2) was first confirmed in Tunisia in February 2000 and has since spread northward and westward, infecting several other countries and islands, including Corsica, where clinical disease was reported in October 2000. BT was again reported on the Island in July 2001, some six months after a vaccination campaign against BTV 2. The molecular relationship between isolates of the BTV 2 Corsican wild-type viruses from 2000 and 2001, and the attenuated BTV 2 vaccine were determined by comparing corresponding sequences of genome segments 2, 7 and 10 with each other and with already published sequences available in the genome database. Complete genetic stability was observed between the isolates of the Corsican BTV 2. There was some divergence between the nucleotide sequences of segment 10 obtained from the wild-type and vaccine virus strains. Based on these differences, primers were selected that could be used in RT-PCR to differentiate between the wild-type and the vaccine viruses.
\end{abstract}

Bluetongue virus serotype 2 / vaccine / genome / RT-PCR

\section{INTRODUCTION}

Bluetongue is a non-contagious, infectious viral disease of domestic and wild ruminants, although clinical signs are usually only seen in sheep and certain species of deer. The bluetongue viruses are arthropod-borne and constitute the type species of the genus Orbivirus within the Reoviridae family.
The genome is composed of ten doublestranded RNA segments [25], which encode at least ten viral proteins. Seven of the viral proteins are structural and form the doubleshelled virus particle. At least three nonstructural proteins (NS1, NS2 and NS3) have been identified $[18,24]$. The inner capsid of BTV is composed of five polypeptides: three minor proteins (VP1, VP4 and VP6) and two major proteins (VP3 and

\footnotetext{
* Corresponding author: e.breard@afssa.fr
} 
VP7) $[12,26]$. The outer capsid is composed of two major viral proteins, VP2 and VP5, which determine the antigenic variability of the BTV $[12,26]$. VP2 is responsible for the adsorption and cell entry of BTV into mammalian cells, hemagglutination, neutralisation and serotype specificity and multimers of VP2 are layered upon a VP5 scaffold [12, 24]. To date, 24 antigenically distinct serotypes of the virus have been identified and many authors have described considerable variations within each serotype [1, 2, 4-6, 10, 11, 22, 28, 29].

The virus is transmitted almost entirely by the bites of certain species of Culicoides biting midges and as a result is restricted to areas where these vectors are present [17]. Transmission only occurs when the adult insects are active. C. imicola is considered to be the most efficient vector in Europe, although other species of Culicoides of lesser importance, have been identified in these areas. The global distribution of BTV lies approximately between latitudes $35^{\circ} \mathrm{S}$ and $40^{\circ} \mathrm{N}$, although in parts of western North America and in China it may extend up to almost $50^{\circ} \mathrm{N}[7,20]$.

BT was first suspected in Tunisia in December 1999. The virus was isolated and confirmed as the BTV serotype 2 (BTV 2) early in 2000. The virus spread westward to Algeria and northward into southern Italy. In October 2000, BTV 2 was confirmed on the Spanish islands of Majorca and Minorca and on the French island of Corsica [30].

Following the isolation and confirmation of BTV 2 in Corsica in 2000, the French Veterinary Authorities decided to systematically vaccinate all the sheep on the island during the winter of 2001 using the South African attenuated BTV 2 vaccine virus [30]. However, in July 2001 outbreaks of the clinical disease were reported in BTV 2 vaccinated flocks. Coincidentally outbreaks of a second BTV serotype, BTV 9, were being reported and confirmed on mainland Italy around this time. This caused great concern to the French Veterinary Authorities in Corsica since there was now the threat of a second incursion of a different BTV serotype onto the Island.

The genome segments 2, 7 and 10 (S2, S7 and S10) of the BTV viruses are used for typing (S2) or for group-BTV detection (S7 and S10). The purpose of this study was to compare these three segments with the wild-type virus strains isolated in 2000 and 2001 (after vaccination) with each other and with the vaccine virus, and to identify differences in the BTV 2 sequences that could help differentiate between the wildtype and vaccine viruses.

\section{MATERIALS AND METHODS}

\subsection{Biological samples}

Blood samples from pyrexic animals were collected in vaccutainers containing EDTA. A $3.0 \mathrm{~mL}$ aliquot of each EDTAblood sample was washed three times with $10 \mathrm{~mL}$ of sterile phosphate-buffered saline (PBS). The red blood cells (RBC) were centrifuged at $1000 \mathrm{~g}$ for $5 \mathrm{~min}$ at $4{ }^{\circ} \mathrm{C}$ after each washing and the supernatant was discarded. After the final wash, the packed $\mathrm{RBC}$ were then resuspended to the original volume with PBS. The blood samples were divided into two equal aliquots. One aliquot was used for RNA extraction and RT-PCR, the $\mathrm{RBC}$ in the other were used for virus isolation in embryonated chicken eggs (ECE).

\subsection{Vaccination}

During the summer and autumn of 2000, 49 outbreaks of BTV were reported in Corsica. Virus isolations made at that time were confirmed as BTV 2 by VNT, and by serotype specific RT-PCR [30]. The South African attenuated BTV 2 vaccine virus (batch 7, Onderstepoort Biological Product, South Africa) was used for the vaccination campaign against BTV 2 on the Corsican island during the winter of 2001 (January to April 2001). About 80\% of the sheep (non-pregnant or over the age 
of 3 months) were vaccinated on the island using the South African attenuated BTV 2 vaccine virus $[31,32]$. In spite of this vaccination campaign, 335 outbreaks of suspected BT were reported between July and September 2001. In 2002, a compulsory new vaccination campaign was carried out. No outbreak was reported in 2002.

\subsection{Vaccine and wild BTV 2 strains}

The vaccine strain sequenced for this study is the South African attenuated BTV 2 vaccine virus. The wild BTV 2 strains sequenced have been isolated in 2000 (before vaccination) [30] and in 2001, during the outbreak between July and September.

\subsection{Inoculation of embryonating chicken eggs}

Individual groups of three ECE were each inoculated intravenously with $0.1-$ $0.2 \mathrm{~mL}$ of a $10^{-1}$ dilution of either washed and lysed blood, homogenised tissue or vaccine virus. The eggs were incubated for 5 days at $35^{\circ} \mathrm{C}$ and examined daily using a cold candling lamp. The embryos that died within $24 \mathrm{~h}$ were discarded. The embryos that died between days 2 and 5 were removed and homogenised in a pestle with sterile sand and Eagles MEM, supplemented with streptomycin $100 \mu \mathrm{g} / \mathrm{mL}$ and penicillin $100 \mathrm{UI} / \mathrm{mL}$, using a mortar to give a final $10 \%$ suspension. The tissue homogenates were clarified by centrifugation at $10000 \times g$ for $10 \mathrm{~min}$ at $4{ }^{\circ} \mathrm{C}$.

\subsection{Virus isolation}

The viruses were isolated from homogenised egg embryos and amplified in monolayer cultures of BHK21 cells (ATTC: CCL-10). Cultured cells in $175 \mathrm{~cm}^{2}$ flasks were inoculated separately with $3 \mathrm{~mL}$ of a $10^{-1}$ dilution of the respective sample, adsorbed for $15 \mathrm{~min}$ at ambient temperature and overlaid with $50 \mathrm{~mL}$ of Eagles MEM, supplemented with $2 \%$ foetal calf serum, streptomycin $100 \mu \mathrm{g} / \mathrm{mL}$ and penicillin $100 \mathrm{UI} / \mathrm{mL}$. Inoculated flasks were incubated at $37{ }^{\circ} \mathrm{C}$ and examined microscopically daily for 7 days for the appearance of cytopathic effects (CPE). If no cytopathic effect was observed, the flasks were frozen and $3 \mathrm{~mL}$ of these cell-cultures were inoculated in fresh monolayer cultures of BHK21 cells. One to three blind passages were achieved.

\subsection{Nucleic acid sample preparation}

Total RNA was extracted from $250 \mu \mathrm{L}$ of washed RBC and from $250 \mu \mathrm{L}$ of tissue preparation using TRIZOL-LS Reagent (Gibco-BRL). The RNA pellets were subsequently dried and then resuspended in $10 \mu \mathrm{L}$ of Rnase free water.

\subsection{Selection of primers (Tab. I)}

\subsubsection{Group-specific primers}

Primers derived from different sequences of BTV 2 S7, previously validated by Zientara et al. [32] were used in BTV group specific assays (RT-PCR S7). The primers derived from the S10 genome were also used in BTV group specific assays (RTPCR S10) [27].

\subsubsection{Serotype-specific primers}

Specific primers, based on the published nucleotide sequence of the S2 genome of BTV 2 (GenBank accession number M21946 [24] ) were designed [32]. A BTV 9 specific RT-PCR was performed using oligonucleotide primers designed and published by McColl and Gould [16]. These BTV 9 serotype specific primers amplified a $805 \mathrm{bp}$ fragment of the BTV 9 vaccine strain. This RT-PCR product was sequenced to confirm the specificity of these primers. These serotype-specific primers (2S2+, 2S2-, 2S9+ and 2S9-) did not amplify the segment 2 of the other 23 serotypes (data not shown). 
Table I. Sequences of the primers used in the group and serotype-specific RT-PCR.

\begin{tabular}{lcccc}
\hline Primers & RT-PCR & $\begin{array}{c}\text { Location } \\
\left(5^{\prime}-3^{\prime}\right)\end{array}$ & Sequences & Reference \\
\hline S7+ & RT-PCR & $1-20$ & GTTAAAAATCTATAGAGATG & Zientara et al. \\
S7- & S7 & $1156-1138$ & GTAAGTGTAATCTAAGAGA & 32] \\
S10+ & RT-PCR & $1-28$ & GTTAAAAAGTGTCGCTGCCATGCTATCC & Wade-Evans \\
S10- & S10 & $798-822$ & GTAAGTGTGTAGCGCCGCATACCCT & et al [27] \\
2 S2+ & RT-PCR & $1-20$ & GTTAAAATAGCGTCGCGATG & Zientara et al. \\
2 S2- & serotype 2 & $2943-2924$ & GTAAGTTGAACAGATCGCGG & {$[32]$} \\
2 S9+ & RT-PCR & $331-350$ & TGGAATGGATGTTATCAGAC & McColl and \\
2 S9- & serotype 9 & $1136-1117$ & GCATTCCGTTGCAATTAACG & Gould [16] \\
S10V+ & RT-PCR & $310-328$ & TGTGAACGAGCAGATTTTA & \\
S10V- & vaccine BTV-2 & $505-523$ & GCCAAGCATCGGGTTAAGG & \\
S10W+ & RT-PCR & $310-329$ & TGTAAATGAACAAATTCTGC & \\
S10W- & wild BTV-2 & $505-524$ & CACCTAACATTGGATTTAAA & \\
\hline
\end{tabular}

\subsubsection{Vaccine- or wild-strain-specific primers}

Specific primers of the $\mathrm{S} 10$ genome of the vaccine $(\mathrm{S} 10 \mathrm{~V}+$ and $\mathrm{S} 10 \mathrm{~V}-)$ or the wildtype (S10W+ and S10W-) strains of BTV 2 were designed and used to help differentiate between vaccination and infection.

\subsection{RT-PCR analysis}

Double-stranded RNA was denatured with methyl mercuric hydroxide as described by Wade-Evans et al. [27]. Reverse transcription and amplification were performed using a single tube RT-PCR method with the "One-Step RT-PCR kit" (Qiagen, Courtaboeuf, France). The amplification of S2, S7 and S10 were carried out using $50 \mu \mathrm{L}$ reaction volumes. The mixtures contained $31 \mu \mathrm{L}$ of RNAse free water, $10 \mu \mathrm{L}$ of $5 \times$ QIAGEN One-Step RT-PCR buffer, $2 \mu \mathrm{L}$ of dNTP mix $(400 \mu \mathrm{M}$ of each $\mathrm{dNTP}$ ), $0.6 \mu \mathrm{M}$ of each primer, $2 \mu \mathrm{L}$ of QIAGEN One-Step RT-PCR Enzyme Mix and $3 \mu \mathrm{L}$ of denatured RNA. The samples were incubated according to the protocols outlined in Table II.

\subsection{Sequencing}

The sequences of segments 2,7 and 10 of the wild BTV strains were determined from RNA extracted from blood collection, suspensions of homogenated chick embryos or supernatants of cell culture, whereas the sequences of the $S 2, S 7$ and $S 10$ vaccines were performed from RNA extracted from the original vaccine batch, supernatants of cell culture, blood from Corsican vaccinated sheep or blood from 14 vaccinated lambs housed in an experimental biosafety pen. Amplified products were sequenced directly by Genome Express (GrenobleFrance). Sequence data were analysed with EditSeq and Megalign Software (DNA Star Inc.).

\subsection{Virus neutralisation test}

Virus neutralisation (VNT) tests were carried out as described in the OIE Manual of Standards for diagnostic tests and vaccines [19], with some modifications.

VNT were carried out in microtitre plates where constant amounts of each BTV type-specific antiserum were added to a tenfold dilution series of each virus sample. 
Table II. Incubation steps of the RT-PCR reactions for segments 2, 7 and 10.

\begin{tabular}{|c|c|c|c|c|c|c|}
\hline \multirow{2}{*}{$\begin{array}{l}\text { RT-PCR } \\
\text { conditions for: }\end{array}$} & \multirow[t]{2}{*}{ RT } & \multirow{2}{*}{$\begin{array}{l}\text { Activation } \\
\text { step }\end{array}$} & \multicolumn{3}{|c|}{ Amplification steps: 40 cycles } & \multirow{2}{*}{$\begin{array}{r}\text { Terminal } \\
\text { extension }\end{array}$} \\
\hline & & & Denaturation & Annealing & Extension & \\
\hline S7 & $30^{\prime}, 45^{\circ} \mathrm{C}$ & $15^{\prime}, 94^{\circ} \mathrm{C}$ & $1^{\prime}, 94^{\circ} \mathrm{C}$ & $1^{\prime}, 45^{\circ} \mathrm{C}$ & $1^{\prime}, 72^{\circ} \mathrm{C}$ & $10^{\prime}, 72^{\circ} \mathrm{C}$ \\
\hline Serotype 2 & $30^{\prime}, 45^{\circ} \mathrm{C}$ & $15^{\prime}, 94^{\circ} \mathrm{C}$ & $1^{\prime}, 94^{\circ} \mathrm{C}$ & $1^{\prime}, 54^{\circ} \mathrm{C}$ & $3^{\prime}, 68^{\circ} \mathrm{C}$ & $10^{\prime}, 68^{\circ} \mathrm{C}$ \\
\hline Serotype 9 & $30^{\prime}, 50^{\circ} \mathrm{C}$ & $15^{\prime}, 94^{\circ} \mathrm{C}$ & $1^{\prime}, 94^{\circ} \mathrm{C}$ & $1^{\prime}, 50^{\circ} \mathrm{C}$ & $1^{\prime}, 72^{\circ} \mathrm{C}$ & $10^{\prime}, 72^{\circ} \mathrm{C}$ \\
\hline S10 & $30^{\prime}, 50^{\circ} \mathrm{C}$ & $15^{\prime}, 94^{\circ} \mathrm{C}$ & $1^{\prime}, 94^{\circ} \mathrm{C}$ & \multicolumn{2}{|c|}{$1^{\prime}, 72^{\circ} \mathrm{C}$} & $10^{\prime}, 72^{\circ} \mathrm{C}$ \\
\hline Vaccine BTV-2 & $30^{\prime}, 50^{\circ} \mathrm{C}$ & $15^{\prime}, 94^{\circ} \mathrm{C}$ & $1^{\prime}, 94^{\circ} \mathrm{C}$ & $1^{\prime}, 51^{\circ} \mathrm{C}$ & $1^{\prime}, 72^{\circ} \mathrm{C}$ & $10^{\prime}, 72^{\circ} \mathrm{C}$ \\
\hline Wild BTV-2 & $30^{\prime}, 50^{\circ} \mathrm{C}$ & $15^{\prime}, 94^{\circ} \mathrm{C}$ & $1^{\prime}, 94^{\circ} \mathrm{C}$ & $1^{\prime}, 51{ }^{\circ} \mathrm{C}$ & $1^{\prime}, 72^{\circ} \mathrm{C}$ & $10^{\prime}, 72^{\circ} \mathrm{C}$ \\
\hline
\end{tabular}

The serum-virus mixtures were incubated for $1 \mathrm{~h}$ at $37^{\circ} \mathrm{C}$. BHK21 cells were then added at a concentration of $10^{5}$ cells $/ \mathrm{mL}$ in MEM supplemented with $5 \% \mathrm{SVF}, 100 \mu \mathrm{g} / \mathrm{mL}$ streptomycin and $100 \mathrm{IU} / \mathrm{mL}$ penicillin. Microplates were sealed, incubated at $37^{\circ} \mathrm{C}$ for 7 days and examined microscopically each day for CPE. Virus titres were calculated using the methods described by Reed and Muench [21]. The serotype of the typespecific antiserum that reduced the virus titre by at least two $\log _{10}$ compared with the virus control in the absence of any BTV type-specific antiserum was designated as the virus serotype.

\subsection{Nucleotide sequence accession numbers}

Sequences of segments 2, 7 and 10 of the BTV 2 Corsican field isolate (2000) and vaccine strain were submitted to GenBank. The assigned accession numbers are AF 356601, AF 346302, AF 481092, AF 481096, AF 481095 and AF 481094, respectively.

\section{RESULTS}

\subsection{Virus isolation}

Twenty-seven blood samples collected from sick and dead sheep from vaccinated flocks showing a high mortality (> 10\%) were examined to confirm the identity of the causal agent. The results obtained using the group and type specific RT-PCR tests, carried out directly on sheep blood, suspensions of homogenated chick embryos or infected cells are presented in Table III. Ten of the BTV isolates were amplified in the cell culture. All of these samples were confirmed as BTV 2 by VNT, type-specificRT-PCR and sequencing (Tab. III). No BTV 9 was amplified from any of these samples.

\subsection{Sequencing}

The alignment of the nucleotide sequences of segments 2, 7 and 10 from sequences of the wild-type BTV 2 made in 2000 and 2001 showed $100 \%$ identity, whatever the origin of the RNA (blood, suspensions of homogenated chick embryos or infected cells). In the same way, the sequences of S2, S7 or S10 PCR amplicons obtained from the vaccine batch were identical to those generated from cells infected with this vaccine or from blood of vaccinated sheep.

A high degree (17.9\%) of variation was observed between the nucleotide sequences of S10 from the BTV 2 wild-type and vaccine viruses. The divergence for S2 and S7 were lower (respectively, 3.5 and 6.4\%).

\subsubsection{Segment 7}

The nucleotide sequences of S7 of the BTV 2 isolates made in 2000, 2001 and the 
Table III. Virus isolation and identification. All blood samples were collected from Corsican sheep with clinical signs during the acute disease between July and September 2001. Group and/or serotype-specific RT-PCR were performed on blood samples, homogenated chicken embryos and cell culture supernatant fluids. Serotype 2 was confirmed by VNT, serotype RT-PCR and sequencing. The 10 wild BTV 2 strains presented in this Table have been sent to Pirbright Laboratory and are referenced.

\begin{tabular}{|c|c|c|c|c|c|c|c|c|c|c|}
\hline \multirow[t]{2}{*}{ Number } & \multicolumn{2}{|c|}{ Blood } & \multicolumn{3}{|c|}{ Embryonated eggs } & \multicolumn{5}{|c|}{ BHK 21} \\
\hline & $\begin{array}{c}\text { RT-PCR } \\
\text { S7 }\end{array}$ & $\begin{array}{l}\text { RT-PCR } \\
\text { serotype } 2\end{array}$ & $\begin{array}{c}\text { Clinical } \\
\text { signs }\end{array}$ & $\begin{array}{c}\text { RT-PCR } \\
\text { S10 }\end{array}$ & $\begin{array}{l}\text { RT-PCR } \\
\text { serotype } 2\end{array}$ & $\mathrm{CPE}$ & VNT & $\begin{array}{c}\text { RT-PCR } \\
\text { serotype } 9\end{array}$ & $\begin{array}{c}\text { Sequences } \\
\text { S2 }\end{array}$ & $\begin{array}{l}\text { Passage } \\
\text { history }\end{array}$ \\
\hline 01.20 & + & + & + & + & + & + & Serotype 2 & - & Serotype 2 & $\mathrm{E}_{1} \mathrm{~B}_{3}$ \\
\hline 01.21 & + & - & + & + & + & - & & - & & \\
\hline 01.34 & + & - & + & + & + & - & & - & & \\
\hline 01.73 & + & + & + & + & + & + & Serotype 2 & - & Serotype 2 & $\mathrm{E}_{1} \mathrm{~B}_{3}$ \\
\hline 01.76 & + & + & + & + & + & + & Serotype 2 & - & Serotype 2 & $\mathrm{E}_{1} \mathrm{~B}_{3}$ \\
\hline 01.649 & + & - & + & + & + & + & Serotype 2 & - & Serotype 2 & $\mathrm{E}_{1} \mathrm{~B}_{3}$ \\
\hline 01.651 & + & - & + & + & + & - & & - & & \\
\hline 01.652 & + & - & + & + & + & - & & - & & \\
\hline 01.671 & + & - & + & + & + & - & & - & & \\
\hline 01.674 & + & - & + & + & + & - & & - & & \\
\hline 01.726 & + & - & + & + & + & - & & - & & \\
\hline 01.729 & + & - & + & + & + & - & & - & & \\
\hline 01.755 & + & - & + & + & + & - & & - & & \\
\hline 01.838 & + & - & + & + & + & - & & - & & \\
\hline 01.915 & + & - & + & + & + & + & Serotype 2 & - & Serotype 2 & $\mathrm{E}_{1} \mathrm{~B}_{3}$ \\
\hline 01.918 & + & - & + & + & + & + & Serotype 2 & - & Serotype 2 & $\mathrm{E}_{1} \mathrm{~B}_{3}$ \\
\hline 01.924 & + & - & + & + & + & + & Serotype 2 & - & Serotype 2 & $\mathrm{E}_{1} \mathrm{~B}_{3}$ \\
\hline 01.1053 & + & - & + & + & + & + & Serotype 2 & - & Serotype 2 & $\mathrm{E}_{1} \mathrm{~B}_{3}$ \\
\hline 01.1082 & + & - & + & + & + & - & & - & & \\
\hline 01.1178 & + & - & + & + & + & - & & - & & \\
\hline $\mathrm{C} 1$ & + & + & - & & & - & & - & & \\
\hline $\mathrm{C} 2$ & + & + & - & & & - & & - & & \\
\hline $\mathrm{C} 3$ & + & + & - & & & - & & - & & \\
\hline $\mathrm{C} 4$ & + & + & + & + & + & + & Serotype 2 & - & Serotype 2 & $\mathrm{E}_{1} \mathrm{~B}_{2}$ \\
\hline C5 & + & + & + & + & + & - & & - & & \\
\hline C6 & + & + & + & + & + & + & Serotype 2 & - & Serotype 2 & $\mathrm{E}_{1} \mathrm{~B}_{3}$ \\
\hline $\mathrm{C} 7$ & + & + & + & + & + & - & & - & & \\
\hline
\end{tabular}

E: Egg; B: BHK 21 cells. RT-PCR S7, S10, serotype 2 and serotype 9 are RT-PCR described in Table I. 
vaccine virus were $1154 \mathrm{bp}$ and had a single open reading frame encoding a predicted VP7 protein of 349 residues. The sequence of the vaccine virus S7 was compared to those of the Corsican strains. A $93.6 \%$ similarity was recorded at the nucleotide level, which increased to $99.4 \%$ when the predicted amino acid sequences were compared.

\subsubsection{Segment 2}

The complete nucleotide sequences of S2 from BTV isolates made in Corsica in 2000 and 2001, and the BTV 2 vaccine virus were $2906 \mathrm{bp}$. The sequences of the Corsican field isolates were identical. There was also a high degree of homology (96.5\%) between the BTV wild-type and vaccine strains.

Segment 2 has a single open reading frame encoding the VP2 protein, which comprises 962 amino acid residues. The predicted VP2 sequence of the Corsican strain (2001) showed 15 amino acid substitutions (1.5\% of divergence) when compared with the vaccine strain. These substitutions were evenly dispersed throughout the S2 gene of the strain (data not shown).

\subsubsection{Segment 10}

The nucleotide sequence of S10 from the BTV 2 vaccine strain showed $82.1 \%$ homology with that of the S10 from the wild-type strains isolated in 2000 and 2001. The alignment of the two sequences are shown in Figure 1. The S10 gene has two in-phase and overlapping open reading frames, which encode the two non-structural proteins NS3 and NS3A, containing 229 and 216 amino acids, respectively. The NS3 predicted amino acid sequence of the BTV 2 vaccine strain showed $94.3 \%$ homology with the wild-type BTV 2 NS3 protein; the majority of the coding mutations that occur within the S10 gene of the vaccine virus resulting in non-conserved amino acid substitutions. Five out of the
12 divergent amino acids are located between positions 149 and 158 (Fig. 2).

\subsection{Specific RT-PCR vaccine or wild strain}

The alignment of the S2, S7 and S10 of the BTV 2 vaccine and Corsican virus isolates showed that the nucleotide sequence of S10 presented the highest degree of divergence between these strains. Primers showing a high level of nucleotide substitution within S10 of the wild-type and vaccine viruses (Fig. 1) were selected and used to examine blood from vaccinated and infected sheep. The results shown in Figure 3 demonstrate that the group-specific primers for S10 BTV amplified the virus from infected and vaccinated sheep while primers specific for S10 of the vaccine virus only amplified the virus from vaccinated sheep. All blood samples, homogenated chick embryos or infected cells listed in Table III were tested by RT-PCR using $\mathrm{S} 10 \mathrm{P}+, \mathrm{S} 10 \mathrm{~V}-$ or S10W+ and S10W-primers. No amplified products were detected with S10V+ and S10V-; all samples were positive with S10W+ and S10W-primers (data not shown). These data indicate that all BTV 2 viruses described in Table III were wild strains.

\section{DISCUSSION}

Bluetongue was first reported in Tunisia in December 1999 and isolated viruses were confirmed as BTV 2 in early 2000. Subsequently, in October 2000, clinical cases of the disease caused by BTV 2 were confirmed in Corsica [30]. In response to this virus incursion, the French Veterinary Authority decided to carry out a vaccination campaign against BTV 2 throughout the island during the winter of 2001 .

In July 2001, outbreaks of the clinical disease were reported in BTV 2 non-vaccinated or vaccinated flocks. The occurrence of suspect clinical BTV, which resulted in 


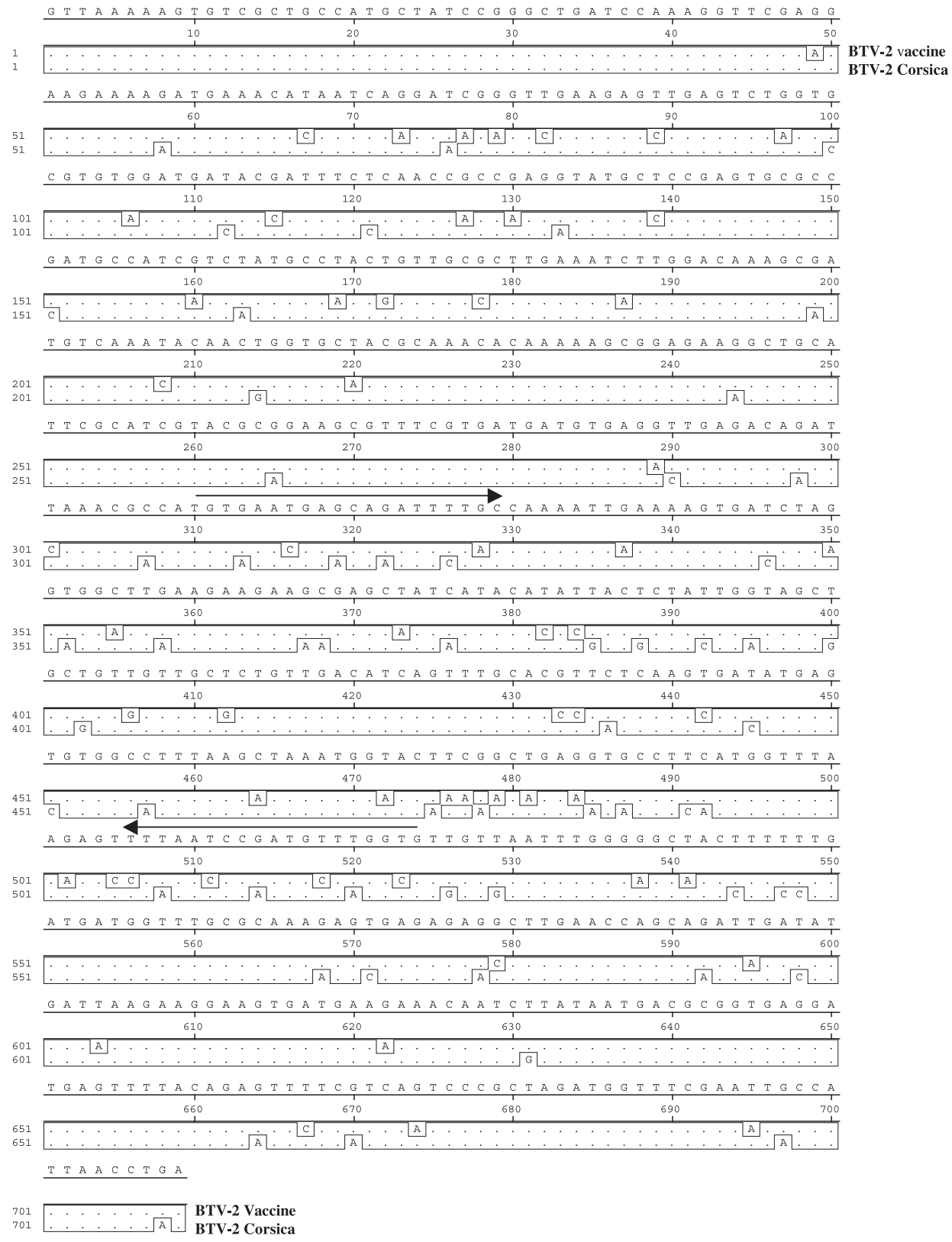

Figure 1. Nucleotide sequences of the S10 genes of the Corsican BTV 2 field isolate and vaccine strain. The start and stop codon are at positions $20-22$ and 707-709, respectively. The identical bases are represented by dots. The arrows represent the primers selected for the specific amplification of the vaccine strain. 


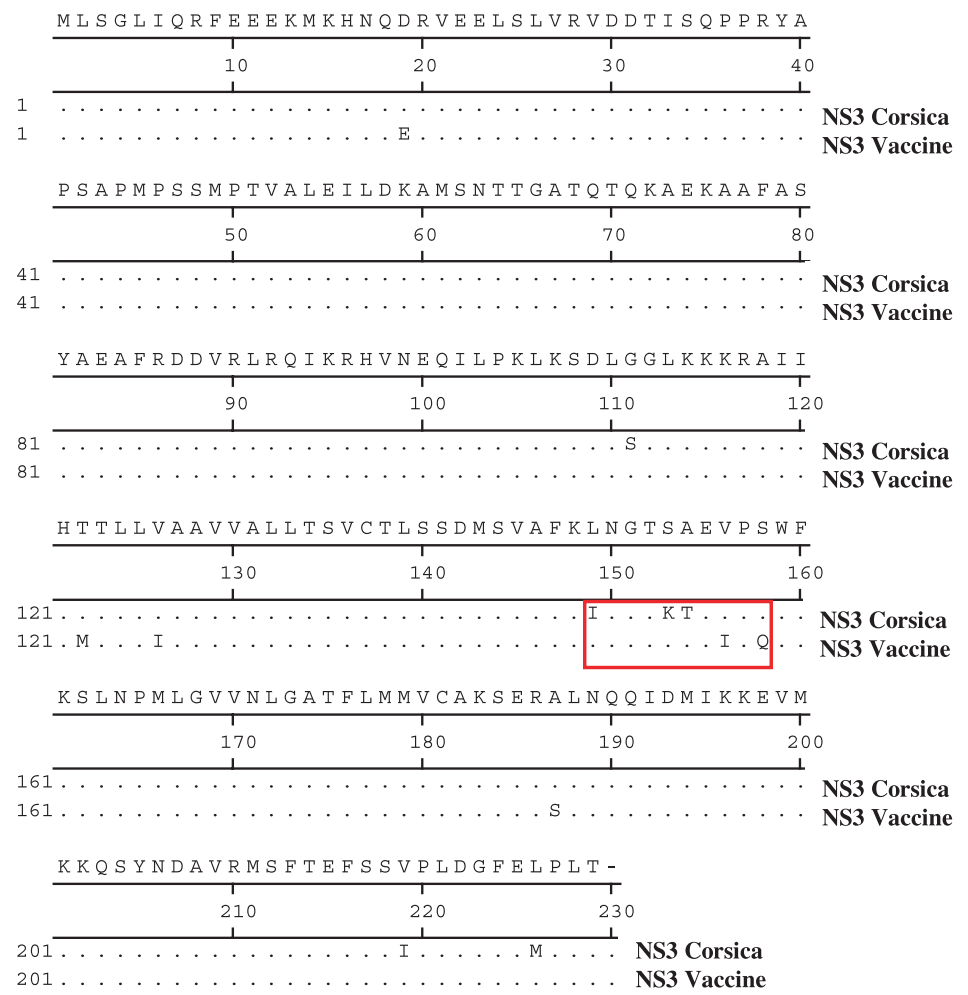

Figure 2. A comparison between the amino acid sequences of the NS3 of the wild and vaccine BTV 2. The major mutations are clustered at positions 149 to 158 (rectangle).

greater than $10 \%$ mortality on some of the vaccinated farms during the summer of 2001, caused considerable concern, particularly because a second BTV, serotype 9 , had recently been confirmed in Italy. These concerns were amplified because the same BTV 2 attenuated vaccine virus had been used on the Balearic Islands of Majorca and Minorca, following confirmed outbreaks of BTV 2 in 2000. However, unlike Corsica since vaccination, the Spanish Veterinary authorities have not reported any cases of BT. The fact that all Corsican sheep had not been vaccinated during the 2001 winter, that some flocks had not been correctly vaccinated (bad storage of the vaccine...) and that the presence of the vector Culicoides imicola was observed in Corsica from June 2001 could explain this second outbreak. Although some of the primary vaccinated sheep were not protected against the subsequent exposure to BTV 2, the morbidity and mortality rates in the vaccinated sheep were 5 to 6 fold lower than the non-vaccinated sheep (personal data).

The causal agent isolated from clinically sick and dead sheep in 2001 was identified as BTV using group-specific RT-PCR and confirmed as BTV 2 by type-specific RTPCR, VNT and sequencing (Tab. III).

BTV was first confirmed using the RTPCR S7 described in the OIE manual [18] in 27 blood samples collected from infected 


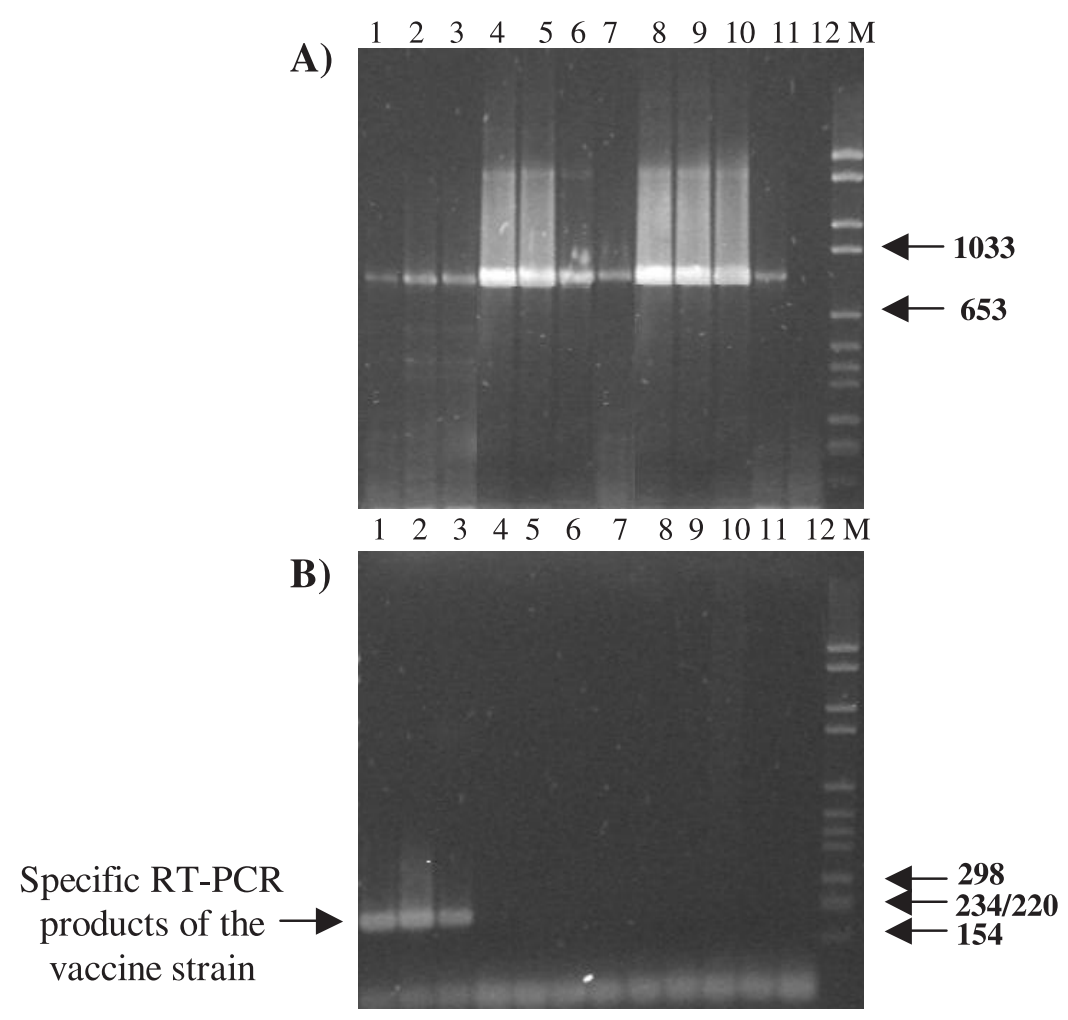

Figure 3. RT-PCR products on BTV RNA isolates from different biological or supernatant samples. RT-PCR samples were analysed by agarose gel electrophoresis as described in the Materials and Methods. The lines M represent the molecular weight marker VI (Roche). Line $1=$ blood sample of vaccinated sheep (18 days after vaccination); lines 2 and $3=$ blood samples of vaccinated sheep (21 days after vaccination); lines 4 to $7=$ blood samples from Corsican sheep infected with the wild-type BTV 2 in 2000; lines 8 to $10=$ blood samples from Corsican sheep infected in 2001 (vaccinated 6 months before the outbreak); line 11 = supernatant fluids from cell culture infected with the BTV 2 Corsican strain; line $12=$ water control. (A) Group specific primers derived from BTV 2 segment 10 (Wade-Evans et al., 1990). (B) Specific primers from segment 10 of the BTV 2 vaccine strain.

flocks. The RT-PCR S10, which is also group-specific, amplified the BTV NS3 gene and had a better sensitivity than the RT-PCR S7 (data not shown). The results of these tests confirmed the presence of BTV in the groups of chicken embryos that died following the inoculation of sheep blood (24/27) (Tab. III). The BTV serotype present in all 27 blood samples, amplified by serotype-specific RT-PCR, either directly from blood or after passage in embryonated chicken eggs, was confirmed as BTV 2. Only ten of these samples readily adapted to growth in BHK cell culture and these were serotyped as BTV 2 by VNT. None of the samples (blood or cell-cultured) were shown to contain BTV 9 after assay by VNT and BTV-9 serotype specific RT-PCR.

The nucleotide sequences generated for S2, S7 and S10 from the BTV 2 wild-type 
strains isolated in 2000 and 2001 showed $100 \%$ identity. We have also sequenced the S2, S7 and S10 of the wild BTV 2 strain from Tunisian sheep blood collected in 2000 (data not shown). The sequences of these RT-PCR products were identical to the S2, S7 and S10 of the Corsican strain. At last, the Italian colleagues of the Terramo Institute have announced that the sequence of the S2 Italian BTV 2 strain shows $100 \%$ homology with the S2 Corsican sequence (AF 356601). Our sequencing results suggest a high genetic stability between the different BTV field strains detected from sheep blood, not only in Corsica but in the Mediterranean basin, over a period of ten to twelve months, in spite of the studies that characterise genetic drift of field strains in defined geographic areas [3]. However, our sequences were determined directly from RT-PCR products (designated consensus sequences). Bonneau et al. [3] have demonstrated by experimental infection that VP2 and NS3/ NS3A gene consensus sequences remain stable throughout the transmission cycle, even if cloning and sequencing DNA from these RT-PCR show the presence of minor variants that could be randomly acquired and amplified by vector insects.

Previous studies have demonstrated that BTV could persist in cattle during several months and that these animals could serve as a reservoir for the viruses during the winter [14]. In this way, the vaccination of sheep during the winter (when few if any field strains were circulating in ovines) and no vaccination of bovines could explain the lack of reassortants and indicate that the live BTV 2 vaccine does not persist in the field by itself.

Sequence data previously generated for segment 2 [8-10] have also shown that viruses of the same serotype are closely related at the nucleotide and amino acid level. Since the Corsican 2000 and 2001 bluetongue viruses and the vaccine virus show more than $95 \%$ homology they are considered to belong to the same cluster.
The VP7 protein is extremely hydrophobic and is a major bluetongue virus group reactive antigen [23]. The VP7 sequence data comparisons between the BTV 2 vaccine and Corsican wild-type strains showed only 1 amino acid change at position 262 (Alanine $\rightarrow$ Serine), indicating that all changes in segment 7 of the BTV 2 vaccine virus were non-conservative (data not shown).

As already observed by Hwang et al. [13], the analyses of the NS3 predicted amino acid sequences of wild or vaccine serotype 2 viruses revealed a high degree of sequence homology and conservation with the NS3 of the other BTV serotypes. Comparisons of the predicted NS3 sequences of the vaccine and the Corsican strains showed that the principal difference is the clustered amino acid change at 149-158. This region contains a chain of 10 amino acid residues which could be involved in the determination of the BTV virulence. Martin et al. [15] have already demonstrated the involvement of the African Horse Sickness Virus segment 10 in the cell exit of another Orbivirus.

The nucleotide sequence divergence between the Corsican and the vaccine strains has permitted the design of primers, which specifically amplify a portion of the S10 of the BTV2 vaccine and wild-type viruses. The specific vaccine or wild strain primers have been tested and validated on RNA extracted from RBC, spleen and lymph node samples from 14 experimentally vaccinated lambs, Corsican vaccinated sheep blood, Corsican infected sheep in 2001 or wild BTV 2 isolates (data not shown). Figure 3 clearly shows the value of using such primers to provide diagnostic PCR that can differentiate between natural infection and vaccination. Implementing such assays is important and will help in our understanding of the epidemiology and spread of BTV in vaccinated areas. The information obtained will also prove invaluable in control and eradication programmes. 


\section{REFERENCES}

[1] Bonneau K.R., Zhang N., Zhu J., Zhang F., Li Z., Zhang K., Xiao L., Xiang W., MacLachlan N.J., Sequence comparison of the L2 and S10 genes of bluetongue viruses from the United States and the people's Republic of China, Virus Res. 61 (1999) 153-160.

[2] Bonneau K.R., Zhang N., Wilson W.C., Zhu J., Zhang F., Li Z., Zhang K., Xiao L., Xiang W., MacLachlan N.J., Phylogenetic analysis of the S7 gene does not segregate Chinese strains of bluetongue virus into a single topotype, Arch. Virol. 145 (2000) 1163-1171.

[3] Bonneau K.R., Mullens B.A., MacLachlan N.J., Occurence of genetic drift and founder effect during quasispecies evolution of the VP2 and NS3/NS3A genes of bluetongue virus upon passage between sheep, cattle, and Culicoides sonorensis, J. Virol. 75 (2001) 8298-8305.

[4] de Mattos C.A., de Mattos C.C., Osburn B.I., MacLachlan N.J., Heterogeneity of the L2 gene of the field isolates of bluetongue virus serotype 17 from the San Joaquin Valley of California, Virus Res. 31 (1994) 67-87.

[5] de Mattos C.C., de Mattos C.A., Osburn B.I., MacLachlan N.J., Evolution of the L2 gene of strains of bluetongue virus serotype 10 isolated in California, Virology 201 (1994) 173177.

[6] de Mattos C.C., de Mattos C.A., MacLachlan N.J., Giavedoni L.D., Yilma T., Osburn B.I., Phylogenetic comparison of the S3 gene of United States prototype strains of bluetongue virus with that of isolates from California, J. Virol. 70 (1996) 5735-5739.

[7] Dulac G.C., Dubuc C., Myers D.J., Afshar A., Taylor E.A., Incursion of bluetongue virus type 11 and epizootic haemorrhagic disease of deer type 2 for two consecutive years in the Okanagan Valley, Can. Vet. J. 30 (1989) 351.

[8] Ghiasi H., Fukusho A., Eshita Y., Roy P., Identification and characterization of conserved and variable regions in the neutralization VP2 gene of bluetongue virus, Virology 160 (1987) 100-109.

[9] Gould A.R., Conserved and non-conserved regions of the outer coat protein, VP2 of the Australian bluetongue serotype 1 virus, revealed by sequence comparison to the VP2 North American bluetongue virus serotype 10, Virus Res. 9 (1988) 145-158.

[10] Gould A.R., Pritchard L.I., Relationships amongst bluetongue viruses revealed by comparisons of capsid and outer coat protein nucleotide sequences, Virus Res. 17 (1990) 31-52.

[11] Gould A.R., McColl K.A., Pritchard L.I., Phylogenetic relationships between bluetongue viruses and other orbiviruses, in: Walton T.E., Osburn B.I. (Eds.), Bluetongue, African horse sickness, and related orbiviruses, CRC Press, Boca Raton, Fla., 1992, pp. 452-460.

[12] Huismans H., Van Dijk A.A., Els J.M., Uncoating of parental bluetongue virus to core and subcore particles in infected L cells, Virology 157 (1987) 180-188.

[13] Hwang G.Y., Yang Y.Y., Chiou J.F., Li J.K., Sequence conservation among the cognate nonstructural NS3/3A protein genes of six bluetongue viruses, Virus Res. 23 (1992) 151-161.

[14] MacLachlan N.J., Nunamaker R.A., Katz J.B., Sawyer M.M., Akita G.Y., Osburn B.I., Tabachnick W.J., Detection of bluetongue virus in the blood of inoculated calves: comparison of virus isolation, PCR assay, and in vitro feeding of Culicoides variipennis, Arch. Virol. 136 (1994) 1-8.

[15] Martin L.A., Meyer A.J., O’Hara R.S., Fu H., Mellor P.S., Knowles N.J., Mertens P.P., Phylogenetic analysis of African horse sickness virus segment 10: sequence variation, virulence characteristics and cell exit, Arch. Virol. Suppl. 14 (1998) 281-293.

[16] McColl K.A., Gould A.R., Detection and characterisation of bluetongue virus using the polymerase chain reaction, Virus Res. 21 (1991) 180-188.

[17] Mellor P.S., Boorman J., The transmission and geographical spread of African horse sickness and bluetongue viruses, Am. Trop. Med. Parasitol. 89 (1995) 1-15.

[18] Mertens P.P.C., Brown F., Sangar D.V., Assignment of the genome segments of bluetongue virus type 1 to the proteins they encode, Virology 135 (1984) 207-217.

[19] OIE Manual of standards for diagnostic tests and vaccines, 2000, pp. 109-118.

[20] Qin Q., Tai Z., Wang L., Luo Z., Hu J., Lin $\mathrm{H}$., Bluetongue epidemiological survey and virus isolation in Xinjiang, China, in: Bluetongue Disease in Southeast Asia and the Pacific, Canberra, Australia, 1996, pp. 67-71.

[21] Reed L.J., Muench H., A simple method for estimating fifty percent endpoints, Am. J. Hyg. 27 (1938) 493-497.

[22] Ritter D.G., Roy P., Genetic relationships of bluetongue virus serotypes isolated from different parts of the world, Virus Res. 11 (1988) 33-47. 
[23] Roy P., Bluetongue virus proteins, J. Gen. Virol. 73 (1992) 3051-3064.

[24] Roy P., Marshall J.J.A., French T.J., Structure of bluetongue virus genome and its encoded proteins, Curr. Top. Microbiol. Immunol. 162 (1990) 43-87.

[25] Verwoerd D.W., Louw H., Oellermann R.A., Characterization of bluetongue virus ribonucleic acid, J. Virol. 5 (1970) 1-7.

[26] Verwoerd D.W., Els M.J., De Villiers E.M., Huismans H., Structure of bluetongue virus capsid, J. Virol. 10 (1972) 783-794.

[27] Wade-Evans A.M., Mertens P.P.C., Bostock C.J., Development of the polymerase chain reaction for detection of bluetongue virus in tissue samples, J. Virol. Methods 30 (1990) $15-24$.

[28] Yamaguchi S., Fukusho A., Roy P., Complete sequence of neutralization protein VP2 of the recent US isolate bluetongue virus serotype 2: Its relationship with VP2 species of other US serotypes, Virus Res. 11 (1988) 49-58.
[29] Zhang N., MacLachlan N.J., Bonneau K.R., Zhu J., Li Z., Zhang K., Zhang F., Zhang L., Xia L., Xiang W., Identification of seven serotypes of bluetongue virus from the People's Republic of China, Vet. Rec. 145 (1999) 427-429.

[30] Zientara S., De la Rocque S., Gourreau J.M., Gregory M., Diallo A., Hendrikx P., Libeau G., Sailleau C., Delecolle J.C., La fièvre catarrhale ovine en Corse en 2000, Epidémiol. Santé Anim. 38 (2000) 133-144.

[31] Zientara S., Grillet C., De la Rocque S., Gourreau J.M., Gregory M., Hendrikx P., Libeau G., Sailleau C., Albina E., Bréard E., Delecolle J.C., La fièvre catarrhale ovine en Corse en 2001, Epidémiol. Santé Anim. 40 (2001) 129-134.

[32] Zientara S., Sailleau C., Dauphin G., Roquier C., Remond E.M., Lebreton F., Hammoumi S., Dubois E., Agier C., Merle G., Bréard E., Identification of the Bluetongue virus serotype 2 (Corsican strain) by Reverse-transcriptase PCR reaction of segment 2 of the genome, Vet. Rec. 150 (2002) 598-601. 